\title{
LE CORBUSIER. STREETS, PROMENADES, SCENES AND ARTEFACTS
}

\author{
Xavier MONTEYS ${ }^{1}$, Pere FUERTES ${ }^{2}$ \\ ${ }^{1}$ Department of Architectural Design, Universitat Politècnica de Catalunya, \\ Av. Diagonal, 649-651, 08028 Barcelona, Spain \\ ${ }^{2}$ Department of Architectural Design, Universitat Politècnica de Catalunya, \\ Pere Serra, 1-15. 08173 Sant Cugat del Vallès, Spain \\ E-mails: ${ }^{1}$ xavier.monteys@upc.edu; ${ }^{2}$ pere.fuertes@upc.edu (corresponding author)
}

Received 19 March 2016; accepted 22 April 2016

\begin{abstract}
The relationship of Le Corbusier with the street is complex and sometimes contradictory. Young Jeanneret seems to be persuaded by certain sites, which we may define as urban scenarios, during his visits to cities like Istanbul in his formative years. Unlike his hometown La Chaux-de-Fonds - identified by a regular set of streets - these places may have been a picturesque counterpoint activated by a significant topography. Streets meandering along a set of 'Dom-ino' houses in the Oeuvre complete, as the tracking rails of a long shot recording, offer a changing viewpoint that may be considered in relation with such casual arrangements. The claim to kill the 'rue corridor' made in Précisions, together with his later writings, deeply contrast with his own comments on an empty Paris in the summer of 1942 - as published in Les Trois Établissements Humains - praising the same streets he pretended to erase by means of operations like the 'Ilôt Insalubre No 6'.

The objective of this paper is to highlight and discuss those contradictions, which can be illustrated by the technical machine-streets conceived for the Ville Contemporaine of 1922 versus the V4 streets formulated in 1947 to reconcile with traditional streets.
\end{abstract}

Keywords: Le Corbusier, street, street space, street design, rue corridor, rue intérieure, V4 street.

\section{Introduction. Six streets}

Within his vast urban production, this essay will address the reflections, critiques and proposals of Le Corbusier about the street. The consistency of the material that elaborates on this specific matter makes it identifiable and distinct from any other manifestation on public space which he projects, as could be parks, squares, urban centres, highways and the very idea of urban fabric, all of which remain excluded in this text.

Le Corbusier frequently makes use of the plans of cities - some drawn by himself - to support his discourse. In Urbanisme (Le Corbusier 1925) alone, one can identify Rouen, Antwerp, Ulm, Minneapolis, Washington, Turicum, Peking, Venice, Khorsabad, Timgad, Palmanova, Monpazier, New York and Chicago, besides Paris, which is a constant reference throughout his work. From these cases, the urban structure, the grid, the regularity of the layout and the geometry of the whole stand, but not the street as an urban space. Something similar happens with the figure-and-background diagrams in which different recognisable fabrics are compared with his urban proposals. Here, the street is not distinguishable from other public spaces, such as parks and squares, which comprise the white and neutral space, left over between the black hatches of buildings.

However, these observations are mixed up with others, in which the street takes on a major importance and which are directly based on an experience of Le Corbusier himself. An experience which goes back to his formative years, when the sketches and the notes filling his Carnets form a collection, which would keep him company with in his future reflections. In these examples, the street appears as a scene and Le Corbusier describes it with the minutest details; relation between buildings and open space, vegetation, topography, orthogonal or winding layouts, ground floor premises or the harmful impact of traffic. Le Corbusier deals with the architecture of street as if an organism, formed by the interaction between all these elements, and based 
on this precise acknowledgement, elaborates his theories about the street.

In a temporary panorama, the relation of Le Corbusier with street goes through different phases not a simple linear progression - which occasionally prove to be contradictory within each other. In general terms, one could suggest that, during the travels in his youth, he draws picturesque and empty streets which affect some of his early proposals. A while later, he asserts that the street should not be thought as a picturesque element. Later on, he claims the traditional street must die. In parallel, he proposes a street thought as a factory. Almost simultaneously, the street transforms into a path leading to a park while he invents a 'rue intérieure' that becomes a part of the building. Later, in 1942, he once more reconciles with the street when the cars unexpectedly vanish during the German occupation of Paris. Finally, with the definition of the so-called V4 (Le Corbusier 1945) - the commercial street described in the 'law of seven routes' - he admits the binding role of the traditional street, and incorporates it as such

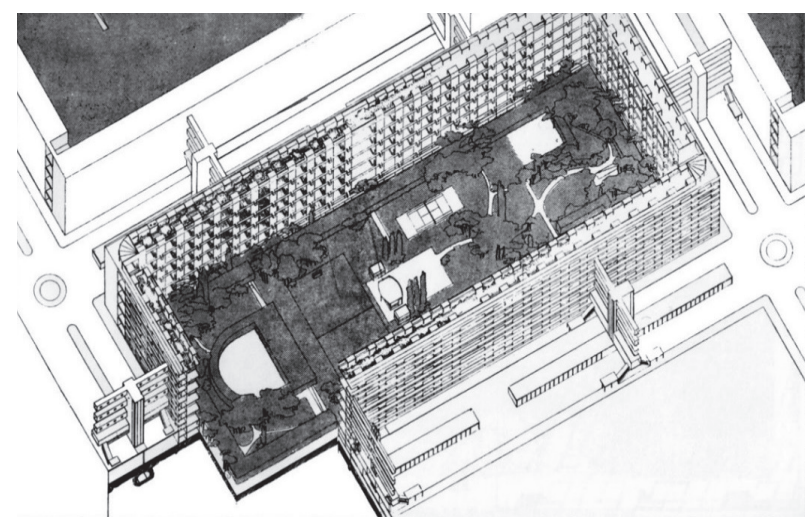

Fig. 1. The 'rue usine' and the 'alveolar' blocks in a view (Le Corbusier 1925)

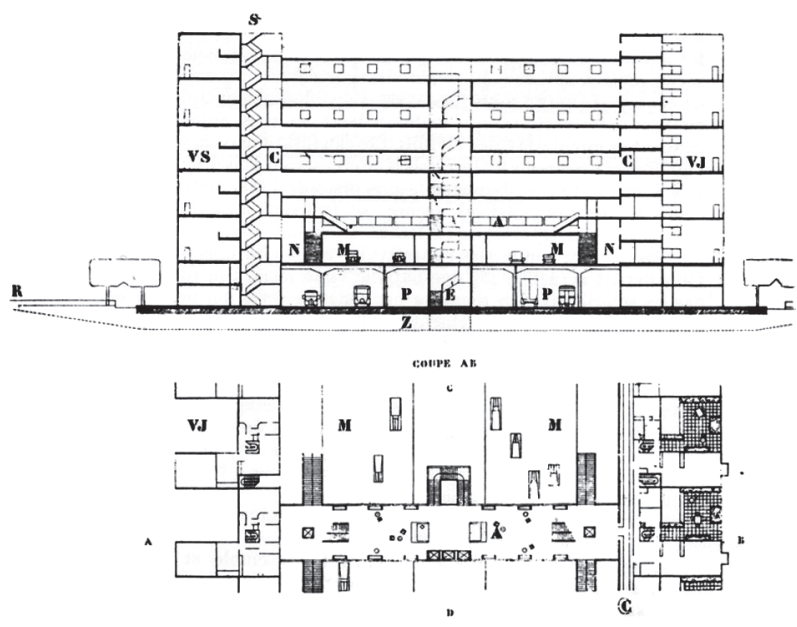

Fig. 2. Cross section and detail of a 'rue usine' (FLC 28788) into his later urban projects. In his texts and proposals, one can easily find a collection of different names for street, which depict this situation: 'rue pittoresque', 'rue usine en longueur', 'rue corridor', 'rue intérieure', 'rue vivante', and finally the exclamation 'Mort de la rue!'.

There is a prolific literature on the urbanism of Le Corbusier, but few critics focus on the street, its evolution and diversity. Stanislaus von Moos is perhaps one of the firsts to approach the street and point out the importance of Paris as "the background for Le Corbusier's redefinition" of this element (2009 [1968]: 188). As Jean Louis Cohen (2007), they both concentrate on the disappearance of the street as the key to understand his urban proposals. This position is endorsed by Jacques Lucan, who also states that "the principle of the abolition of courtyards goes hand in hand with the rejection of the corridor-street" (2009: 382, translation by the authors) ${ }^{1}$. The diversity of sources which are dealt with here take the discussion to a more complex and overlapping scenario of reflections about the work of Le Corbusier in this field.

This essay results from a review of Le Corbusier's proposals, drawings and writings published between 1923 and 1953 and it is divided into six parts, each one supported by a project, an example or a text. These items of a diverse nature intend to illustrate what Le Corbusier understood, described and designed as streets over the years. The essay does not always follow a chronological order, sometimes linking analogous conceptions separated by a certain lapse of time and sometimes pointing out dissimilar streets that coexist in a single urban project.

\section{One. Rue usine en longueur}

In the project for a Ville Contemporaine of three million inhabitants of 1922 (Le Corbusier 1925: 157-235), the street which provides service to the blocks described as 'alveolar' by Le Corbusier (Fig. 1) is, in fact, a building with great complexity. With a thorough observation, one can reasonably doubt whether the urban pattern is a juxtaposition of the mentioned blocks of apartment buildings with suspended alveolar gardens - the so-called 'Immeubles-Villas' - or, in fact, the pattern is nothing but a stretch of street, along with the buildings it interconnects through a system of elevator towers and footbridges (Fig. 2).

In favour of the second option, one can refer to a preliminary project of 'Immeubles-Villas' from the same year (Le Corbusier-Saugnier 1923: 206-209) en-

1 Other authors (Dunnett 2000; Hutter 2016) consider the urban proposals of Le Corbusier in a linear evolution leading to a city without streets. 
visaged with services to house 120 superimposed villas. The section of the project shows two 'corps du logis' separated by an access mechanism of tower and footbridges, which extend below the courtyard where the services are located. The analogy between this central space and the streets of the Ville Contemporaine could not be more explicit. Nevertheless, the relative transposition of the street with respect to the apartments, allows them to overlook an ample communal park shared by the neighbouring buildings, in an order, references of which can be found in Paris, like the gardens of Palais-Royal - of $200 \times 100$ meters, with a one fourth of the area - or the Monceau park, cherished and studied by Le Corbusier - of $400 \times 200$ meters, with the same dimensions used in the urban proposal.

The word 'street' is, in this case, quite imprecise. Le Corbusier describes the streets connecting the alveolar blocks as factories. The street "is a new type of organism, a sort of stretched-out workshop ${ }^{2}$, a home for many complicated and delicate organs [...] If this type of street, which I have called a 'workshop', is to be realized, it becomes as much a matter of construction as are the houses with which it is customary to flank it, and the bridges which carry it over valleys and across rivers". Bridges and viaducts, and not regular paved roads on flat land, seem to shape this particular street: "The modern street should be a masterpiece of civil engineering and no longer a job for navvies." (Le Corbusier 1947 [1925]: 175).

These factory-streets (Fig. 2) - measuring 50 meters in width - split in two levels of circulation. The ground floor level houses a roadway intended for goods supply, including a cargo area on the axis. Some six meters above, a deck supported on 'pilotis' is designed for passenger vehicles with a central canopy of parking space. Every 200 meters, there is a public transportation stop and a staircase equipped with a set of lifts and service elevators - designed as a part of the public transportation system - that connect both levels of circulation with the entry corridors of the villas by means of footbridges, the lower one housing an 8-meter-wide public hall. According to Le Corbusier, all these connecting elements at different levels are part of the street, including the garage for the inhabitants: "The 'roadway' ${ }^{3}[\ldots]$ is continued vertically by means of vast staircases (with lifts and goods lifts) each serving 100 to 150 maisonettes; and its use is extended at various levels by means of footbridges which cross the road and become a part

\footnotetext{
2 Le Corbusier refers to this new organism in the original version (1925) as an 'espèce d'usine en longueur'.

3 The original text in French by Le Corbusier (1925) refers to "rue" (street) and not to "roadway".
}

of the corridors on to which the doors of the maisonettes open." (Le Corbusier 1947 [1925]: 227).

It is not strange that he would call it a longitudinal factory-street, since it already seems to be dedicated solely to transportation and supply. Sidewalks on the upper deck, immerse in this huge machine, may illustrate the inconsistency of pedestrians walking along a street that is not actually intended for them. Even the façades of the buildings turn their back to the street, as Le Corbusier himself specifies (Le Corbusier 1925: 205), with the configuration of an urban space which, paradoxically, still remains as 'rue corridor', such as the ones he condemned in Urbanisme.

The section of a street in New York City - as illustrated in Urbanisme - (Fig. 3) must have been observed as a useful reference, showing five levels of superimposed metropolitan and regional railways and a layout of connecting passageways. The street seems to be no longer conceived as public space but as the place for infrastructures. It is a machine of mobility, comparable to the monumental intermodal station which concentrate the air transportation, the trans-continental lines and highways, accommodated in the very centre of the Ville Contemporaine and confined by four cruciform glass towers on the sides.

However, beyond its 'industrial' configuration, this street establishes a link with the residential buildings. It extends under the villas in two floors to accommodate a huge 'machine' to provide amenities such as private parking slots, door-to-door supplies, household and laundry services or 24 hour catering in a residential

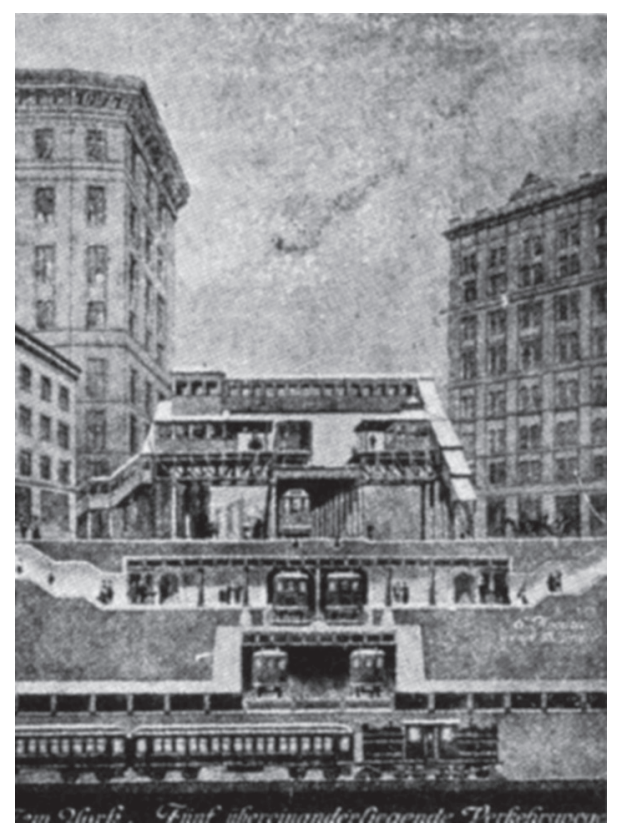

Fig. 3. "New York : A street with five levels of railroad and stations" (Le Corbusier 1947) 

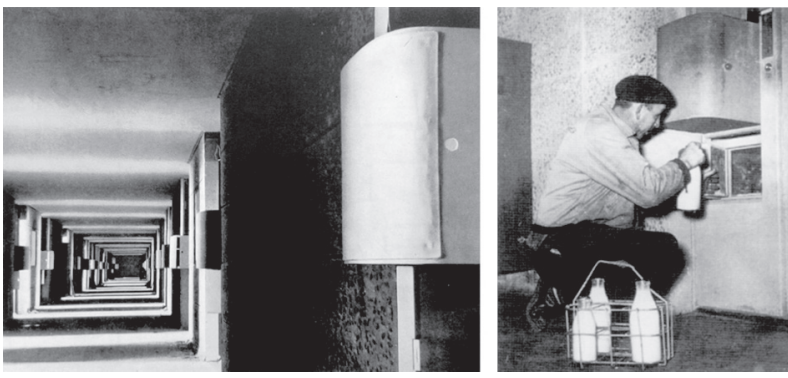

Fig. 4. 'Unité d'Habitation'. A 'rue intérieure' (Le Corbusier 1953: 205) and the daily delivery (Monteys 1996: 28)

organisation comparable to that of the 'ApartmentHotels' which emerged in North America at the beginning of the century ${ }^{4}$.

The raison d'être of the factory-street lies within the lifestyle which was foreseen for these villas and, in any case, it is inconsistent with the existent street. In subsequent proposals, the street is dissociated, isolating the vehicular traffic in a highway, raised up on 'pilotis' as the apartment blocks would do. The factory-street, as an infrastructure of mobility, goods supply and service distribution, would remain forgotten.

\section{Two. Rue intérieure}

The most genuine street we probably associate with Le Corbusier is the 'rue intérieure', a conflicting definition of an interior street that actually names the entry corridors of the 'Unité d'Habitation' (Fig. 4) erected in Marseilles between 1945 and 1952, but dating back to 1935 when described for the first time in the Ville Radieuse. To be precise, Plate VR2 names the 'rues en l'air' (Le Corbusier 1935: 158), also described as 'rues horizontales intérieures' (p. 158) and 'rues horizontales superposées' (p. 166). In the same Plate VR2, it is also specified that the elevators are a public service which extends the urban system to all floors in the redent buildings, just as he reinforces in the plan for the new city of Antwerp (Le Corbusier 1935: 273). In this context, we suggest to observe the 'rue intérieure' as a domesticated and plausible version of the former machine-like streets connecting the 'alveolar' blocks of the Ville Contemporaine.

In this street which acts as a corridor, the intention to resolve the access to apartments along with the good supplies is, once back, present. If one removes the vehicular traffic from the 'rue usine' of 1922, what is left is a group of services and connections which form a

\footnotetext{
4 There is a variety of expressions to define these residential buildings with community services, such as 'Non-housekeeping Apartment Houses' or 'Apartment-Hotels' (Puigjaner 2014).
}

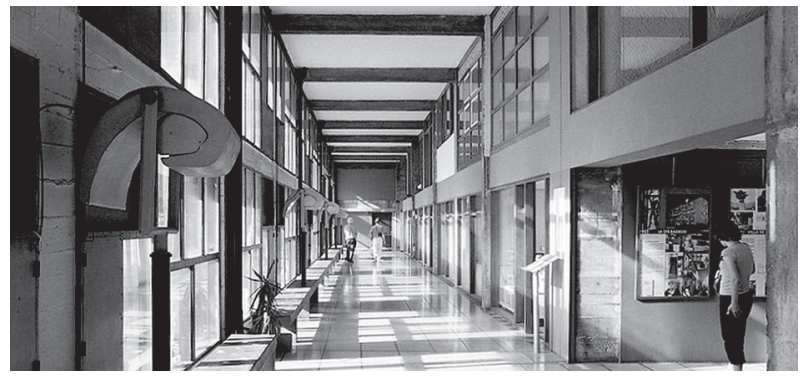

Fig. 5. The gallery on the seventh level

three-dimensional grid, which now, in the absence of cars, can integrate into the interior of the building in a much simpler and more humanised way, preserving some its characteristic features and adapting them to the new situation.

Nevertheless, its character as a street, conferred by Le Corbusier, allows to keep considering a building such as the 'Unité d'Habitation' in the terms of vertical city. In this way, the elevators can still be considered as urban services and the small hotel located on the seventh floor, with barely 20 rooms, as the successor of the comprehensive catering system of the Ville Contemporaine.

One of the most notable topologic changes is, precisely, the displacement of the service area to the seventh floor - in fact, the third one of the superimposed streets - which allows liberating the ground level by means of lifting up the building over 'pilotis'. An apparent liberation which would definitely be responsible for the disappearance of the street as such. In addition to the hotel, a new commercial mall emerges to support the goods supply, so that the greengrocer or the milkman have a direct access to the residents' fridge - a change in scale and closeness when compared to the former 'rue usine'.

The commercial street, with a height of two stories, is displaced towards the west façade in a way which facilitates one to define it clearly as a gallery (Fig. 5), rendering it distinct from the rest of the access streets with its large openings. This gallery-street can be considered as a predecessor - raised from the ground - of the street which would later be defined by Le Corbusier as V4, the street of daily goods supply, which reinforces the conception of the building as a vertical city.

The gallery also draws an analogy - as observed by S. Von Moos (2009: 159) - with another one in the Phalanstère, the social palace which Charles Fourier describes as a community place par excellence (Fourier 2014). The 'rue-galerie' named by Fourier after the Louvre's ones has a decisive importance as a meeting 
place for the inhabitants of the Phalanstère. Along with the gallery on the fourth floor of the Unité, it is also a protection against bad weather - a feasible precedent of the Unité as a 'social condenser'.

The 'rue intérieure' of Marseilles is also a consequence of the former attempt to conceive the street as a factory. A machine which extends with 'rues horizontales intérieures' "sur lesquels ouvrent les portes des villas", intricately linked to the apartment tried out in his residential and urban projects over the years, each time narrower and deeper (Monteys 1996), which eventually resulted in a street with lined up houses. It seems obvious that there is no other space which corresponds better with the criticised 'rue corridor' than this 'rue intérieure'.

\section{Three. Les rues n'ont plus de voitures. Paris été 1942}

In the opening section of Urbanisme, Le Corbusier refers for the first time to an empty Paris in summer of 1924: "The temporary interruption in the life of a great city resulted in my thinking in the end that I was perhaps being carried away by the grandeur of my subject, that I was being swept beyond the borders of reality". However, when cars are back in October 1, he reiterates his determination to change the city, and not his approach to urban mobility in terms of efficiency: the city "is too old. The torrent can no longer keep to its bed." (Le Corbusier 1947 [1925]: 15).

There is a second text published in La Ville Radieuse which refers once again to Paris under the explicit title "Vacances 1932" (Le Corbusier 1935: 7). Now the situation is reversed and he narrates the shock of returning to city from nature, which he crudely criticises for its unhealthiness and overcrowding in a complete contrast with life in open air which he experienced during holidays. It is therefore a coherent text with a discourse to completely transform the constructed city, blurring the boundaries between the nature and the built environment.

Ten years after that second report, Le Corbusier is moved by a very different experience in a Paris without cars during the German occupation of WWII. The description "Paris été 1942" included in Les Trois Etablissements Humains (1945) is much more vivid and extensive, but does not seem to match with the context of this book. The text does not have an argumentative continuity with what follows this reflection and nothing in the previous pages makes this argument foreseeable. We can simply suggest that it offers an autonomous point of view, and its message disrupts, in a certain way, the contents of the book.
Paris summer 1942. Streets have no cars, the city is in silence, the air is pure, June illuminates this victory under the sky of Ile-de-France: the pedestrian is king.

Streets and boulevards appear doubled in width: there are no cars! The threat of crashing no longer exists, the free spirit discovers architecture: the architecture of Paris, the summit of the West since the Middle Ages until today. We observe. Indeed, it is Paris that shows off.

Paris shows toughly engraved houses, drawn in right-angle - strongly, naturally, unquestionably straight-lined. The Parisian has constructed square houses, erect and firm houses. This willingness has been further emphasized by the multiplication of window frames and doors, by the design of each floor. Paris is right-angled, strict, clear, without dissimulation. Straight is queen, a sign of the spirit.

We understand the virtue of the crusaders, of princes, of kings, of emperors before these signs of severe and unwavering firmness. The builders of houses had an unwavering morality before this first era of mechanisation that - after a hundred years - has distorted everything, has allowed the lie. Since architecture has been taught in schools, under the sign of the academies, it now tears construction apart from truth.

Paris is gray because of it masonry, green by its parks, blue cobalt mixed with crimson by its extraordinary sky of gentleness. Paris is rigorous, solid, tight, indisputable. In this Paris summer 1942, without cars and silent, poetry bursts - a solid, tight, firm, designed, written poetry.

Things we thought of utopia are now present: the royalty of the pedestrian. This silence of the street, the serenity of the passerby, the possibility of observing, of looking up to the floors with adequate proportions. This unity of stones and this unity of windows whose scale is the result of a tournament confronting human needs to the building technics.

Paris summer 1942 that we must remember, we must think about it, we must take into consideration to make important decisions. Paris 1942 has reinstated the dignity of the building, the conceivable splendor of cities: Notre-Dame, Concorde, the Tuileries, Faubourg-Saint-Germain. The reinstated dignity of the pedestrian allows citizens to watch their city. We will remember it all, later on, as witnesses. This unique time in the history of Paris will never come back again! (Le Corbusier 1945: 148-149, translated by the authors).

Observing the city in these conditions was possible only due to the absence of cars, which was obviously strengthened by the drop in the amount of daily routine activity because of the German occupation. In this 

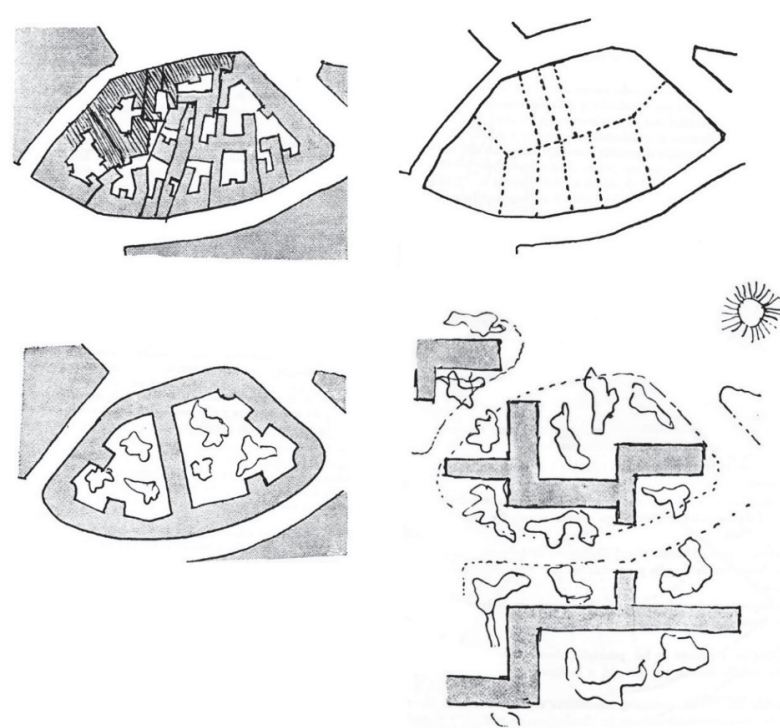

Fig. 6. A process of urban renewal in four stages (Le Corbusier 1946a: 84-86)

reflexion, reappears the attentive observer, who is capable of seeing the streets as Charles-Édouard Jeanneret once did during his youth travels. With this change in point of view, the street traced as a hyper-functional element destined to the circulation and goods supply built for the speed and the efficiency - can once again be perceived as an urban space, in which its attributes stand out. Moreover, it can be concluded that the problem may not be the configuration of the street as a 'corridor', if adequate conditions exist.

\section{Four. Mort de la rue or Rue corridor}

In the pages of Urbanisme - and with Paris usually at the background - Le Corbusier depicts a discouraging panorama about the street. It is perceived as a capital problem of large cities. In the text, he develops a comparison between the operations which must take place in the city, with an analogy to 'medicine' and 'surgery'. With these concepts, he expresses two possible ways to undertake a solution for the problems of traffic congestion and poor conditions in housing. Between the two options, Le Corbusier resolutely chooses 'surgery' - the radical one - and leaves aside the more partial solutions of 'medicine', signified by modest and timid interventions on the urban fabric and buildings.

Much later, while explaining his conception of urbanism in conferences held in Latin America, even 'surgery' seems be inadequate to explain his proposal and he claims emphatically: "Il faut tuer la 'rue-corridor'?" 5 (Le Corbusier 1930: 167) in order to develop the

\footnotetext{
5 "Il faut tuer la rue-corridor !" ('The "corridor street" must be destroyed!') is written in a plate that illustrates a lecture focused on
}

plan Voisin for Paris; on which he would keep insisting, during many other conferences to which he attends.

In Manière de penser l'urbanisme, Le Corbusier makes the relationship between the street and the building explicit through four sequential diagrams (Fig. 6). This time, he takes a whole block surrounded with others, to represent a fragment of the urban fabric. The drawings, despite being generic, clearly contextualise the challenges of urbanism he considers, representing different stages of the setting out of the problem. The drawings depict a clear notion of progress, from the point of departure - a block with inadequate inner courtyards - until the scenario envisaged by Le Corbusier, comparable to the solution which he proposes for the 'Îlot Insalubre No 6' in Paris (Le Corbusier 1938), which seems to be a reference for this situation. As Jacques Lucan remarks, the suppression of the corridor-street involves abolishing such courtyards, as part of a hygienic strategy to open the city to sunlight and $\operatorname{air}^{6}$ (Lucan 2009: 382).

The second drawing illustrates a process of reparcelling, as a necessary stage to control geometrically the result. In other words, it is a radiography which makes the property and the structure of the land visible, providing a certain feasibility.

The third one, however, is the drawing of a project. In this case, buildings take the form of a perimeter strip with some prominent volumes towards the interior which result in the formation of communal courtyards, a substantive difference in reference to the initial situation. The drawing shows a type of intervention, which can be compared to some previous examples of social housing in Paris - the 'habitations à bon marché' - or to some reconstruction operations taking place simultaneously in various cities affected by the war Le Corbusier may well know. His intention would probably be to show the unsatisfactory results of some proposals that apply 'medicine' instead of 'surgery', as expressed in his own terms.

In the scenario which Le Corbusier proposes, as depicted in the fourth drawing, buildings are made independent of the street and the park becomes continuous. The vaguely drawn lines of the initial streets transform into a 'réseaux pittoresque' of paths as in

the plan Voisin for Paris, attended on 18 October 1929 at "Amigos de las Artes" in Buenos Aires (Le Corbusier 1930: 195). Later, he will use the expression "Mort de la rue" ('Death of the street'), as in Plate 3 of sketches for a lecture on 19 June 1934 at the Circolo Filologico Milanese (Consonni et al. 1999).

6 Even though recognising the unhealthiness of many inner courtyards in the urban fabric of Paris, it is remarkable to notice that the apartment of Le Corbusier in Rue Jacob was located in the interior of a block, surrounded by greenery and trees, as described in detail by J. R. Alonso Pereira (2015: 109-118). 
the Ville Radieuse, maintaining its sinuous layout, in a similar way which he named "le chemin des ânes" (Le Corbusier 1925: 5), the 'pack-donkey's way'. A path replaces the traditional street, missing all of the urban activity contained in between the buildings and their ground floors; probably, too high a price to pay for solving a problem of traffic congestion and poor conditions in housing by means of 'surgery'.

However, we must point out that the perspectives drawn to condemn the street - as published in Manière de penser l'urbanisme or in La maison des hommes (Fig. 7) - may suggest different reflections from a contemporary point of view. The opinion of Le Corbusier is clearly expressed in his "Il faut tuer la rue-corridor!" (Fig. 8) but in fact, a few minor modifications in those perspectives would probably be enough to improve the situation, accepting the contradictions caused by subsequent layers of urban sedimentation, so that the results do not become traumatic for the collective memory.

If only automobiles could be removed from these scenes, we may find those spaces recognisable and stimulating, as if they were illustrations of the text "Paris été 1942". Some of the drawings - with a slight curve in the slope or trees lining a street with a constant rhythm of windows - result in urban scenes which are still familiar today. These places have survived in our cities and are intensely inhabited - scenarios with their viewpoints, with a portion of sky and rows of aligned windows. These intuitive drawings fail to convey the need for transformation Le Corbusier pretended. On the contrary, they are felt to be up-to-date since they do not have an expiration date, just like the city itself.

\section{Five. La rue vivante. The V4 street}

About V4, the following can be read in the enunciation of the rule of the Seven Ways in the point "Urbanisme et la règle des $7 \mathrm{~V}^{\prime \prime}$ :

Here we come to the lives of families and individuals. This is the "rue vivante par excellence", la Grand-Rue of tradition. Often Vs 4 follow existing bridle paths, easy, and usually winding roads, not made by human genius, but by the passage of much traffic. These roads cover the land with a harmonious network. They have nearly always penetrated to the centre of the town. They may be called Main Street or Broadway or "Grand-Rue". It is in these streets that the necessities of daily life may be found (the butcher, the baker, the market, etc.), the trades and professions (electricians, locksmiths, chemists, dentists, shoemakers), the pastimes (cinemas,
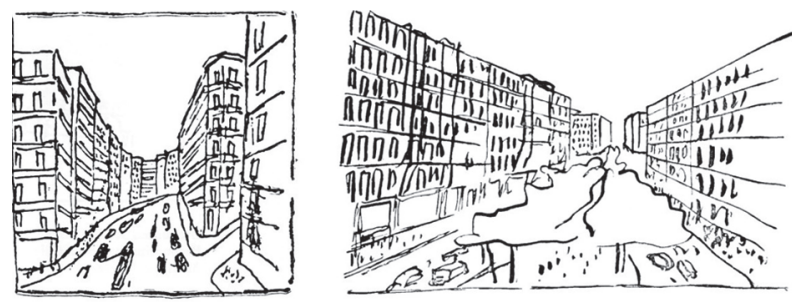

Fig. 7. Two drawings of a 'rue corridor' (Le Corbusier 1946a) (de Pierrefeu, Le Corbusier 1942)

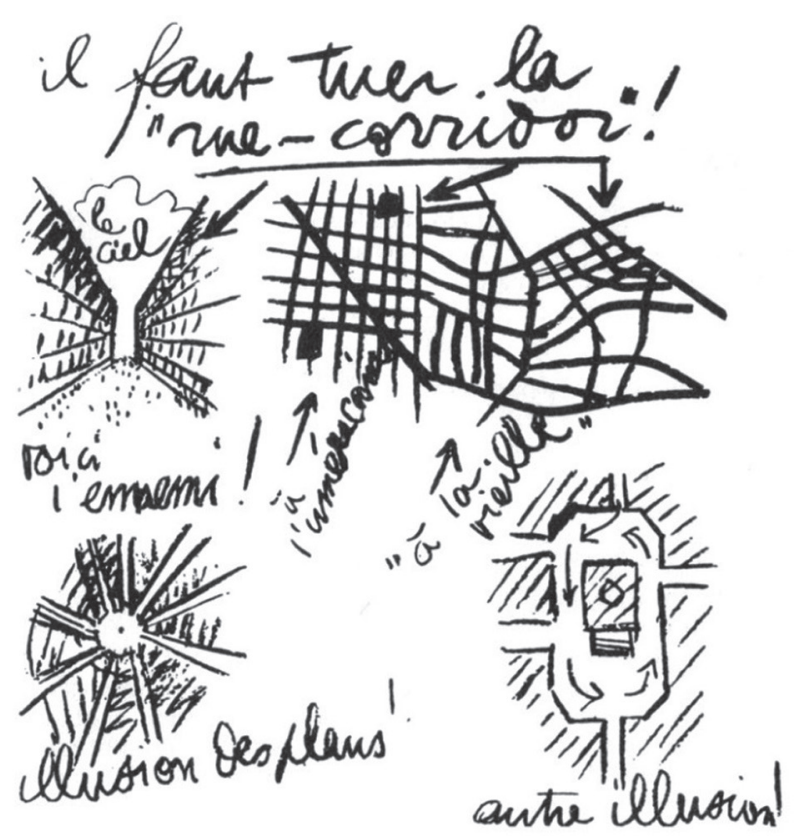

Fig. 8. "Il faut tuer la 'rue-corridor'!" (Le Corbusier 1930)

libraries, conference halls, cafés), security (the police) and so on (Le Corbusier 1953: 96).

The V4, the only one to which he refers as a street: "V4: rue marchande du secteur" (Le Corbusier 1945: 48), a genuine commercial street, expresses in a convincing manner the change of Le Corbusier's opinion about the street. The street, all inconveniences of which were addressed in previous years, is sinuous, with the legacy of the pack-donkey's way, calm and traced with the usage and by the routine. Perhaps the most eloquent name for it would be 'rue vivante' and it can be found in the antipodes of 'rue usine'. The news is not its position against 'machinism' but the fact that it is an adopted street, that it already existed and that it would be compatible with the layout of the new city. The news is precisely maintaining it, something almost unusual in Le Corbusier's urbanism.

This explicit formulation of a 'rue marchande du secteur', has a precedent, perhaps unaware, in the reform of old city centre of Barcelona, which was inte- 
grated into the general proposal of the plan Macià in 1933. In this reform, a scheme appears with clarity, in which parts of some blocks and unhealthy streets are demolished in order to open green spaces inside the larger lots, surrounded by the preserved existent streets (Fig. 9). The Roman precinct, Rambles, Hospital and Carme, a fragment of Nou de la Rambla and Sant Pau, as well as Portaferrissa, the area of Sant Pere, Montcada, Argenteria and Rec Comptal are all maintained as such. Contrary to what would take place later on - with the sequence of images of 1946 - Le Corbusier maintains the main commercial streets which could be observed as the very first manifestation of V4: "the characteristic streets are maintained as pedestrian paths, free from traffic" (Le Corbusier 1935: 307, translated by the authors). Perhaps Le Corbusier takes up again this operation in the rule of the Seven Ways because he has now a theory which justifies maintaining these streets and naming them as V4.

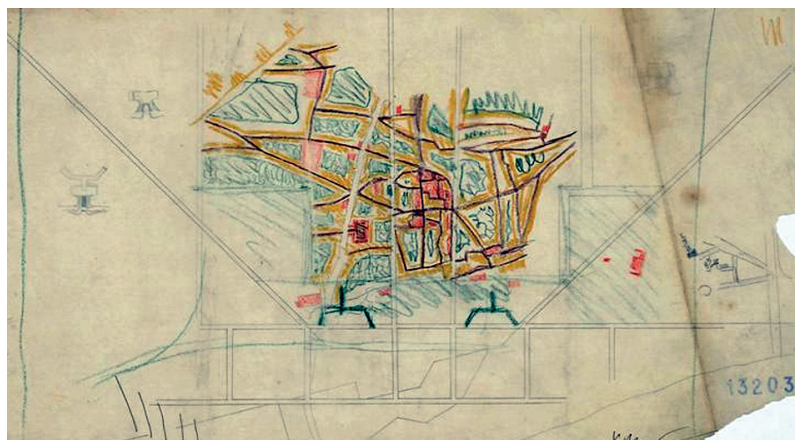

Fig. 9. Study to transform the old city centre of Barcelona (FLC 13203)

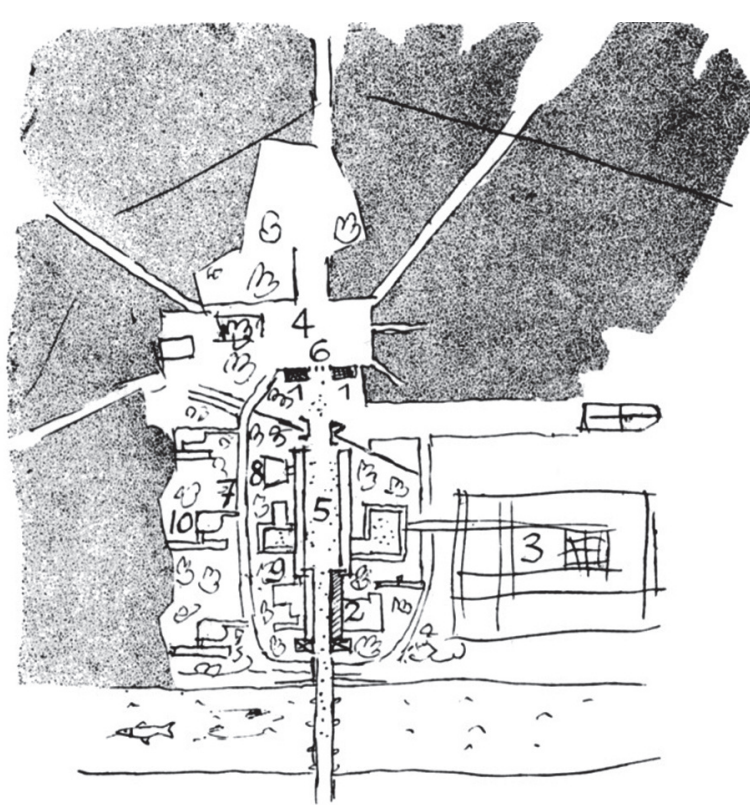

Fig. 10. A draft proposal to transform the old city of Orléans (Le Corbusier 1946b)
An element which must be kept in mind is that the definition of V4 street is not done through a drawing, but through a description of uses, by a comprehensive list of business premises located on the street, from the cafe to the police station, passing by the shoemaker, the dentist or the butcher. No drawing could have defined these uses and atmosphere with such precision without turning into a photo essay. These V4 are drawn in some of his urban proposals which incorporate the theory of 7V, as in Marseille-Sud (FLC 23114: 1946), Meaux (FLC 21477: 1957) or in Berlin, where the boulevard Unter der Linden and Friedrichstraße are contained - in a preliminary sketch - by some irregular building blocks (FLC 23979: 1958).

However, the drawing with the greatest interest is perhaps, a small hand drawn sketch which illustrates the role of one of these streets saved from destruction, the Rue Royale of Orléans (Fig. 10), which remains anonymous in the text: "Here is a town (which shall be nameless). Bombardments have spared us two little palaces (1) and a fragment of royal road of Louis XV (2)" (Le Corbusier 1946b: 62). However, the scale in which these sketches were drawn makes it impossible to distinguish precisely how they actually are. It is the description which works. The text permits, much better than the drawing does, to appropriate something which already exists and which, in this manner, remains out of the design of the new city.

These streets - not designed but preserved or assimilated - saved from demolition in his proposals of final years, represent a self-critique, in a certain manner. They return the commercial street of 'rues intérieures' back to the city, removing them from the private domain and restoring its quality as public space. They are the habitual streets, of daily use, and they have the ability to leave the park of the green city and its trails for the Sundays.

\section{Six. Rues courbes. Drawings and pictures of a young Jeanneret}

In this up-and-down evolution of streets in his urbanism, with advances, regressions and options - which prove contrary on occasions - some elements that seem to be missing could be considered as reflections, though diffident, of fragments of cities which he visited in his youth, before becoming Le Corbusier. Obviously, suggesting this, we are also conscious of doing it from today's point of view, inserted in an urban culture which has incorporated many elements which probably, in the mid-20th century, had no place since the necessities were quite different. But it is also true that architectural critics as a collective have taken certain intellectual pleasure in pointing out the validity of 


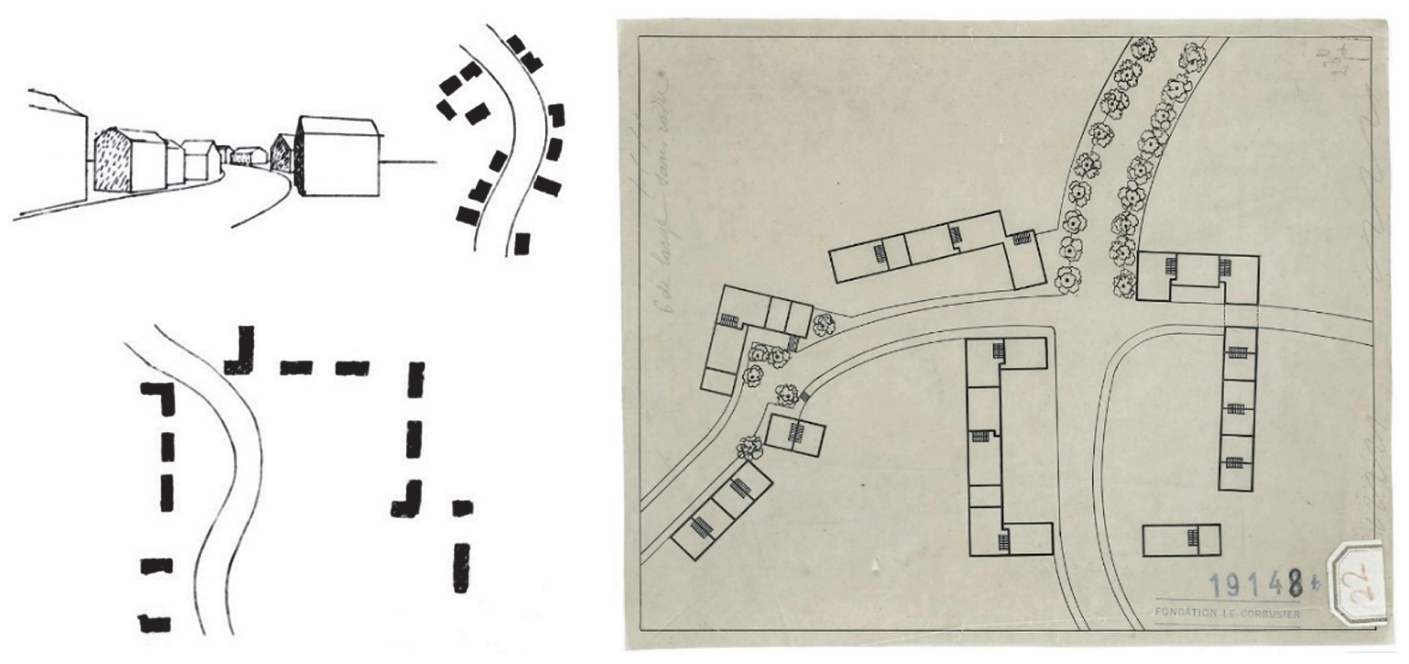

Fig. 11. Left. Curved streets in Urbanisme (Le Corbusier 1925). Right. A 'Dom-ino' neighbourhood (FLC 19148)

Le Corbusier's works in too many occasions some of which were little critical.

Now we have a more inclusive comprehension of the city and a much greater sensibility about the implicit sedimentation inherent in the whole urban system. The contemporary city adds on layers over the existent ones, does corrections and modifications with a moderate accuracy, but never assumes that it starts from scratch on a blank white page. In this sense, different proposals of Le Corbusier also form a group of layers. They are all rewritten proposals over the previous ones, of which some of the earliest could be qualified with no doubt as picturesque.

The drawings of urban details, made with a scenographic sensitivity rather than a structural one, indicate that, in a certain moment, he knew how to see and enjoy this picturesque character. His repeatedly contrary observations of the curved street were tinged with his first proposals of 'Dom-ino' houses. Later, they vanish and only seem to appear as the footpaths and trails of his parks, converted into an element of connection for the green city. The notes taken in cities like Istanbul (Fig. 13), Prague or Budapest from a direct experience ${ }^{7}-$ and which can almost be described as epicurean - differ from the sketches and observations from the time when he studies the layouts of historic cities on their plans.

The events about which young Jeanneret notes down in his Carnets should have called attention of someone whose daily urban experience was La Chauxde-Fonds, a city with a soft inclination, with parallel

\footnotetext{
7 A recent essay by Ricardo Daza on the 'voyage d'Orient', of 1911 is a key reference to clarify and systemize the graphic and written material produced by Jeanneret in this period (Daza 2015).
}

streets, rectilinear and certainly predictable. In this sense, the drawings of sloping streets, with curvilinear layouts, with very little or almost no cars, asymmetrical and distorted with perspective tricks of foreshortened buildings, represent an absolute contrast with the Swiss city. At the same time, we can recognise the influence of Camillo Sitte's texts which he would later distance from: "I read Camillo Sitte, the Viennese writer, and was affected by his insidious pleas in the direction of the picturesque in town planning" (Le Corbusier 1947: [1925] 16). Although the influence of these drawings is hardly noticeable in his works ${ }^{8}$, there are some occasions in which they seem to have been incorporated, namely the curvilinear layout of Cité-jardin aux Crétets for La Chaux-de-Fonds (FLC 30267), where streets and buildings follow a unified irregular rhythm; the first associations of 'Dom-ino' houses and the groups of orthogonal buildings and curved streets (Fig. 11, Left) drawn in Urbanisme, all of which follow the same criteria.

On these rare occasions - barely a few examples - Le Corbusier seems to have found a way to make building with curved streets compatible by producing a cinematographic effect for someone on movement: "Therefore arrange the houses on either side of your winding road (so pleasant to ramble in) in blocks at right angles to each other. Standing free against the sky they make the view (as the eye sees it), which then becomes an ordered thing" (Le Corbusier 1947: 221). One of the proposals for the organisation of 'Dom-ino' houses in 1914-15 which he publishes in Euvre Complète 1910-1929

\footnotetext{
8 “...the visual documents of Jeanneret's visit to Prague in 1911 seem subsequently to have vanished from is memory [...] For instance, he did not use any examples from Prague in his planned study La Construction des Villes" (Spechtenhauser 2002: 171).
} 


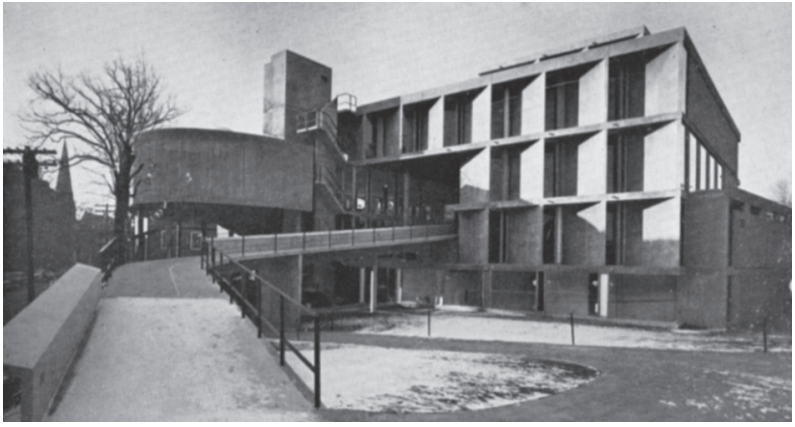

Fig. 12. Location plan and view of the Carpenter Center for the Visual Arts (Le Corbusier 1965: 61)

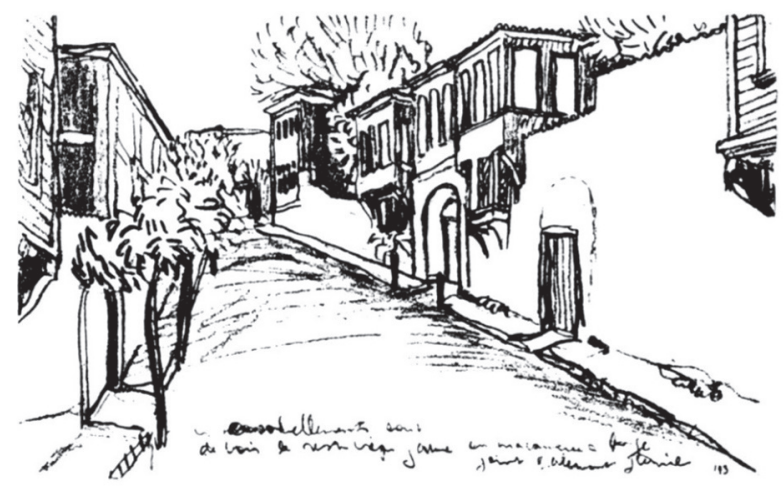

Fig. 13. A sketch of Istanbul by Charles-Édouard Jeanneret, 1911 (Le Corbusier 1925: 71)

(Le Corbusier, Jeanneret 1937: 26) and which is done by 'correcting' the alignment of buildings along the curved street, has an unusual degree of detail (Fig. 11, Right). The buildings, in the form of an elongated ' $\mathrm{L}$ ', are scenically located, contradicting with the "right angles to each other" which he claims. They get closer to and move away from the street and even formalize a gate with its complexity which unmistakably proclaims that one has entered a place.

This almost picturesque formalisation recalling the atmosphere of some urban scenarios he visited and sketched during his formative years (Fig. 13) would be lost for good in his proposals, in which the paths across the parks would not have the possibility to 'dance' with the building as in this peculiar and specific case of 'Dom-ino' houses. We can identify a similar gesture - we may venture to suggest - only in the flamboyant building of Carpenter Center for the Visual Arts in Cambridge, Massachusetts, of 1961-64 (Fig. 12). A building which, at the end of Le Corbusier's work, intertwines with a curvilinear sloping street which passes through - in a way that no other ramp does it in his other projects - to be able to link obliquely Quincy Street with Prescott. A curvilinear ramp-street traced like those pack-donkey's ways, winding and tiring but, at the end, also inspiring.

\section{Discussion}

This essay would like to point out a recurrent omission: the street, and suggest a complex framework around it. From this point of view, it is preferable to gather the different meanings that the street has in Le Corbusier, as they are not the elements of a coherent evolution that can be easily isolated, but overlapping and contradicting ones. We can observe continual advances and regressions that affect the conception of this urban element; probably the most elemental, but also the most defining, vigorous and less 'global' of our cities.

Le Corbusier's urbanism has the attraction of its contradictions and interferences, e.g. when a new type of street appears before it can even be defined, as in the above-referred case of the plan Macià and its avant la lettre V4. It is essential though to consider urban and architectural proposals along with critiques - like the one of the 'rue-corridor' - and literary descriptions as the text "Paris été 1942". All this material put together has the added value of a collection and allows a better understanding of the complexity that the street acquires in his work.

Therefore, we should consider to what extent architectural critics have depicted the urban thought of Le Corbusier as a linear and evolutionary one, in a rather simplistic way. He once claimed that the corridor street should be eradicated - literature about other street expressions in his work seem to have followed the same course.

\section{References}

Alonso Pereira, J. R. 2015. El París de Le Corbusier. Barcelona: Reverté.

Consonni, G.; Meneghetti, L.; Tonon, G. 1999. Le Corbusier, Urbanismo: Le sei tavole della conferenza al Circolo Filologico milanese: Giugno 1934. Bergamo: Lubrina.

Cohen, J. L. 2007. Usine ou paysage? La rue des modernes, in F. Ascher, M. Apel-Muller (Eds.). La rue est à nous tous! Paris: Au Diable Vaubert.

Daza, R. 2015. Tras el viaje de Oriente: Charles-Édouard Jeanneret - Le Corbusier. Barcelona: Fundación Caja de Arquitectos.

Dunnett, J. 2000. Le Corbusier and the city without streets, in T. Deckker. (Ed.). The modern city revisited. London: Spon Press.

Fondation Le Corbusier Archive (FLC). Paris, France.

Fourier, Ch. 2014 [1822]. Théorie de l'unité universelle, in L'Art social de la Révolution à la Grande Guerre. Anthologie de textes sources, INHA [online], [cited 22 October 2015]. Available from Internet: http://inha.revues.org/5256.

Hutter, M. 2016. Le Corbusier: cities without streets, in Experiencing Cities. New York: Routledge, 118-122. 
Le Corbusier-Saugnier. 1923. Vers une architecture. Paris: Crès.

Le Corbusier. 1947 [1925]. The city of to-morrow and its planning. London: The Architectural Press.

Le Corbusier. 1930. Précisions sur un état présent de l'architecture et de l'urbanisme. Paris: Crès.

Le Corbusier. 1935. La Ville radieuse. Boulogne-sur-Seine: Éditions de l'Architecture d'aujourd'hui.

Le Corbusier; Jeanneret, P. 1937. CEuvre Complète 1910-1929. Zurich: Girsberger.

Le Corbusier. 1938. L'Îlot insalubre No 6. Paris: Tournon.

de Pierrefeu, F.; Le Corbusier. 1942. La maison des hommes. Paris: Plon.

Le Corbusier. 1945. Les trois établissements humains. Boulognesur-Seine: Denoël.

Le Corbusier. 1946a. Manière de penser l'urbanisme. Boulognesur-Seine: Éditions de l'Architecture d'aujourd'hui.

Le Corbusier. 1946b. Propos d'urbanisme. Paris: Bourrelier (Concerning Town Planning. London: The Architectural Press, edition 1947).

Le Corbusier. 1953. Euvre Complète 1946-1952. Zurich: Girsberger.

Le Corbusier. 1965. Euvre Complète 1957-1965. Zurich: Les Éditions d'Architecture.

Lucan J. 2009. L'espace convexe : Le Corbusier et le plan livre, Chapter 20 in Composition, non-composition: Architecture et théories, XIXe-XXe siècles. Lausanne: PPUR.

Monteys, X. 1996. La gran máquina: La ciudad en Le Corbusier. Barcelona: Serbal.

Puigjaner, A. 2014. Ciudad sin cocina: el Waldorf Astoria, apartamentos con servicios domésticos colectivos en Nueva York, 1871-1929: PhD dissertation, Universitat Politècnica de Catalunya [online], [cited 5 September 2015]. Available from Internet: http://hdl.handle.net/10803/279387.

Spechtenhauser, K. 2002. Prague, Chapter 8 in S. von Moos, A. Rüegg (Eds.). Le Corbusier before Le Corbusier. New Haven: Yale University Press.

Von Moos, S. 2009 [1968]. Le Corbusier: elements of a synthesis. Rotterdam: 010 Publishers.

\section{XAVIER MONTEYS}

PhD. Professor. Author of Los paisajes de Le Corbusier; Le Corbusier. Obras y proyectos among other articles and books on Le Corbusier.

As a member of the research group HABITAR (http://habitar. upc.edu), his academic and research aims are also focused on studying the human habitat as the environment in which current lifestyles are developed, from the domestic sphere to the urban context.

\section{PERE FUERTES}

$\mathrm{PhD}$. Associate Professor. His doctoral dissertation centered on the Indian architecture of Le Corbusier. Author of Chand LC 4445 Capitol. Third trip of Le Corbusier to Chandigarh, MarchApril 1952; Luces y sombras sobre el palacio del Gobernador. As a member of the research group HABITAR (http://habitar. upc.edu), his academic and research aims are also focused on re-inhabiting the existing urban fabric and buildings as part of a strategy based on reprogramming and adapting architecture and cities to new paradigms of inhabitability. 